\title{
VEGETABLE PRODUCTION IN SAUDI ARABIA: PROTECTION COEFFICIENTS AND RELATIVE EFFICIENCY
}

\author{
Raga Mohamed Elzaki Ali ${ }^{*}$, Maha Abdelfattah Ibrahim Saied ${ }^{2}$ and \\ Momtaz Nagy Mohamed Elsebaei ${ }^{3}$ \\ * Corresponding author E-mail: rmali@kfu.edu.sa
}

A R T I C L E I N F O
Original Article
Received: 22 March 2019
Accepted: 10 June 2019
doi:10.5937/ekoPolj1902457E
UDC 658.5.012.7:[338.432:634(532)

Keywords:

PAM, Winter Vegetables, Cost Benefit Ratios.

JEL: Q10, Q17, Q18

\begin{abstract}
A B S T R A C T
This research investigated the protection coefficients and relative efficiency of winter vegetables by using the domestic and tradable inputs of some selected winter vegetables in Saudi Arabia to explore the economic incentives of local vegetables. The data was analyzed using gross margin and Policy Analysis Matrix (PAM) approach. The outcomes of this research revealed that the eggplant constitutes a highest gross margin as compared to other local vegetables. Moreover, the private price of potato output is more than their parity price. The producers of tomato crops are nearly protected. However, during the study period, the producers of tomatoes, zucchini, and ladyfingers were subsidized and largely competitive on their exports. Furthermore, the study indicated that the government supported eggplant and cucumber vegetables. The research suggests for establishment of international trade collaboration to reduce fees and removal of policy distortions to rise the incentives for vegetable producers.
\end{abstract}

(C) 2019 EA. All rights reserved.

\section{Introduction}

The Kingdom of Saudi Arabia (KSA) is an industrial country; the agricultural production remains as a substitute sector after other economic sectors, such as the petrol sector.

1 Department of Agribusiness and Consumer Science, College of Agriculture and Food Science, King Faisal University, AlAhsa, Hofuf, Saudi Arabia, 31982 and Department of Rural Economics and Development, Faculty of Animal Production, University of Gezira, Sudan, telephone:+966535541089, e-mail: rmali@kfu.edu.sa, ORCID-ID (https://orcid. org/0000-0002-4993-8505?lang=en).

2 Department of Agribusiness and Consumer Science, College of Agriculture and Food Science, King Faisal University, AlAhsa, Hofuf, Saudi Arabia, 31982 and Department of Agricultural Economics, Faculty of Agriculture, Ain Shams University, Cairo, Egypt, e-mail: msaied@kfu.edu.sa, ORCID- ID (https://orcid.org/0000-0001-7779-8004)

3 Department of Agribusiness and Consumer Science, College of Agriculture and Food Science, King Faisal University, AlAhsa, Hofuf, Saudi Arabia, 31982 and Department of Agricultural Economics, Faculty of Agriculture, Ain Shams University, Cairo, Egypt, e-mail: melsebaei@kfu.edu.sa, ORCID ID (https://orcid.org/0000-0002-8308-5868)

http://ea.bg.ac.rs 
The agricultural holdings land in KSA is estimated as more than 34.2 Donum $^{4}$ (GAoS, 2018), whereas the total cultivated areas was estimated as one million ha in 2017 (MoEWA 2017) and the total cultivated areas of the vegetable production estimated as 432.8 thousand Donum (GAoS, 2017).

In previous years, the percentage share of GDP acquired from agricultural production (crops, forestry, and fishery) has declined from 2.7\% in 2016 to 2.5\% in 2017 (MoEWA, 2018). Figure 1 reveals that fodder production constitutes the highest production through (2014 - 2017), this is allied with high activities practicing in the country, while vegetable (closed field) production is estimated to have lower production during the same period (MoEWA, 2018).

Figure 1.Total crop production (ton), KSA, 2014/2017.

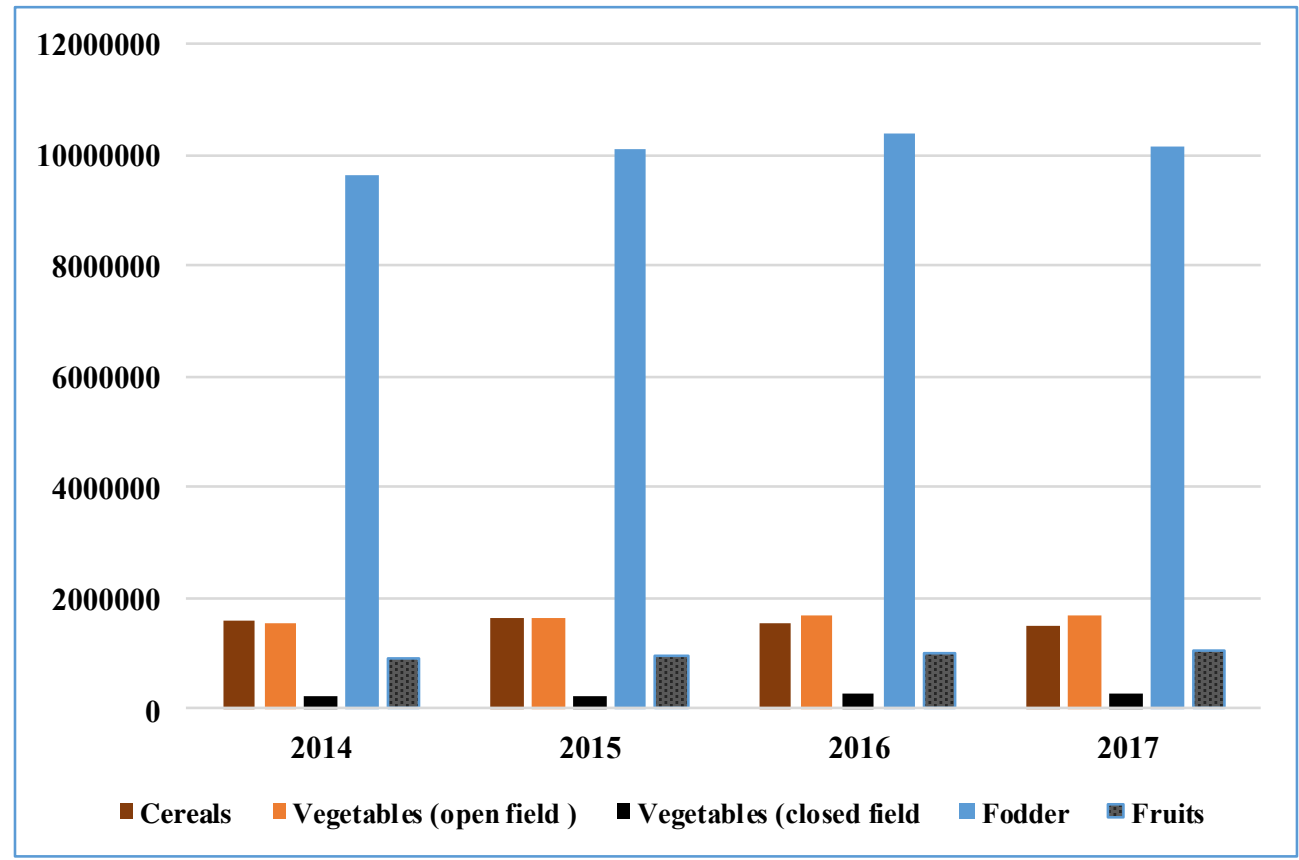

Source: MoEWA, 2018

The most common cultivated vegetables in KSA are tomatoes, potatoes, zucchini, eggplant, okra, carrots, dry onion, cucumber, melon, and watermelon. Figure 2 shows that watermelon comprises the highest production in comparing with other cultivated vegetables and these might be peripherally attributed to the increase of watermelon demand or enhancement of production technologies for watermelon, whereas carrots constitute the lowest production.

4 One donum $=1000$ square meter, $=0.247$ acre. 
Figure 2. Total production of vegetables of open field (ton), KSA, 2017.

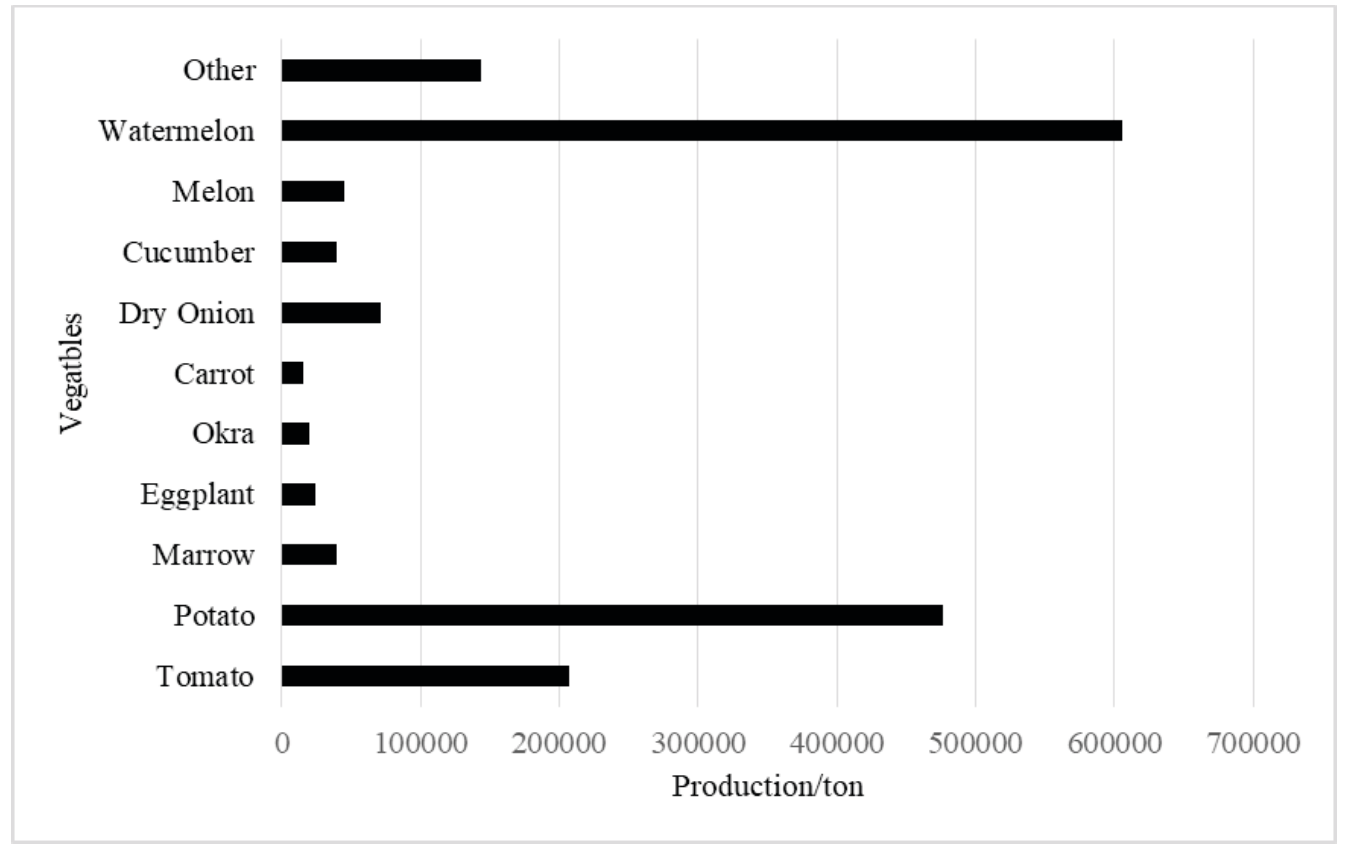

Source: MoEWA, 2017

However, as the population increases, the consumption of agricultural crops increases. Keeping in view the gradually increasing population of $\mathrm{KSA}$, the government is making intensive efforts through five-year development plans to develop the agricultural sector (MoEP, 2018). The goals of Saudi Arabia government are seriously involved in the agriculture industry, so, Saudi Arabia government is engaged to practise advanced technologies for crop production to directly satisfy the local demands for food commodities and likewise to fill a gap of food security. At present, the winter vegetable crops in KSA involve various challenges such as economic, climate, and social factors. Most economic factors facing vegetable production are raised because of world prices of vegetables items, as KSA is obviously influenced by the world financial crisis. Besides other economic challenges such as fluctuations of some prices of inputs (the imported fertilizers and seeds) and the price competition of the local production with the imports. The climate factors can be addressed as changing and rising in annual temperatures, sandstorms, and lack of rainfall, which directly or indirectly affect vegetable production. Even though the country has developed infrastructure and other facilities, vegetable production persistently face low productivity per unit area with high costs of production. Besides, the scarcity of water is considered to be the most challenging factor of agricultural production in the country. Moreover, the water demand for agricultural purposes is approximately $84 \%$ of the total water demand (MoWE, 2015). The social factors in vegetable production can be categorized as poor management, insufficient extension services, and lack of awareness towards implementation of modern technologies of the cultural practices. 
The key goal of this study is to analyse productivity and profitability of winter vegetables and compare the vegetables according to rates of cost benefit ratios (CBRs). Besides, the study examines the economic incentives through analysing the PAM for winter vegetables, focusing on protection coefficients of winter vegetables and ranking them according to relative efficiency (comparative advantages) by using domestic and tradable inputs of some selected winter vegetables in Saudi Arabia.

\section{Literature Reviews}

Engaging in an efficient use of resources is a major area of concern across the world. However, most countries are searching for more sustainable practices to save money and to be more competitive (Albornoz and Geraldo, 2018). Numerous PAM approach studies have attempted to analyse the co-efficient and relative efficiency on agricultural crops (e.g. oil and vegetables crops, cereals, and cash) in the world. Rahman et al. (2016) used the PAM approach for maize in Bangladesh, reporting that maize production is competitive in Bangladesh and can be a good substitute for maize import, even when the international price of maize varies slightly, and further indicated that maize is profitable at the farm. Recently, Rashid and Matin's (2018) study using PAM for selected pulse crops found that revenue and input transfer were negative, which indicated that government policies negatively affect pulse producers and implemented an input subsidy policy in the crop sector to offset the higher cost of production.

Furthermore, research performed by Quddus and Mustafa (2011) in Pakistan to measure the advantages of most production crops, reported that the efficiency of economics for the production of wheat did not receive any protection and the prices received by farmers were below the import parity prices. Moreover, it confirmed that cotton production is efficient in term of economic prices. Similarly, Javed et al. (2006) argued that cotton crop is taxed in Pakistan. Temesgen et al. (2014) using PAM to analyse rice in Ethiopia, committed that the net effect of policy intervention is reduced profitability of rice production, and a removal of policy distortions would substantially increase profitability and rice farmers would receive lower revenue than they would have in the absence of policy distortions. Moreover, Yao (1997a) found that rice has an obvious comparative advantage over its rival crops, however Hoang and Tran (2019) study the comparative advantages of alternative crops of rice, coconut, and pomelo using PAM and confirmed that, pomelo fruit obtains the strongest competitiveness followed by coconut and rice; respectively. Scheiterle and Birner (2018) used the PAM approach to examine the comparative advantage of maize production in Ghana and confirmed that maize crop has the prospective to increase productivity to safeguard food security. Moreover Lateef et al. (2017), applying the PAM approach for analysing the influence of investment in agricultural scientific research on some cereal crops, argued that the investment was profitable for domestic producers of the wheat.

Fang and Beghin (2000) stated that fruits and vegetable markets are free markets in China with no explicit price distortions. A previous study performed by Atiya (2007) examined competitiveness and comparative advantages of tomatoes in Syria, 
measuring that the tomato sector is fairly protected and has benefited from the subsidies concerning irrigation and the protection of the local production by imposing high tariff quota on tomato imports, according to the agricultural calendar. Ul-Mulk and Khan (2013) investigated PAM of winter vegetables and established that pea production is nationally profitable for import substitution; however, it is not profitable for export promotion. Furthermore, Arsanti and Bohme (2008) clarified that vegetable farming is profitable with regard to the private and social profits, as well as competitive and comparative advantages.

\section{Research Methods}

\section{Study Area and Data Collection}

The present study was conducted in the Al-Hasa region (in western KSA) where a bulk of the crop production is cultivated in this region. In the Al-Hasa region, rainfall occurs in the winter season; consequently, the study selected winter vegetables (open filed system), named as tomatoes, eggplants, zucchini, cucumber, ladyfinger, and potatoes to satisfy the study objectives. The study depends on secondary data, which are collected from the relevant institutions interrelated to current study during the 2016 -2017 season. The information and data covering the winter vegetables is collected to achieve the objectives of the study. Specific data used for constructing a PAM table were collected that comprised the information on both tradable and non-tradable inputs. Tradable inputs comprise the inputs which can be traded internationally in the world market (imported fertilizers, pesticides, insecticides, etc.) while the non-tradable inputs are mainly domestic factors that are not traded internationally (labour items, land, local capital, etc.). Stoforos et al. (2000) revealed that most inputs come in as a mixture of some tradable and non-tradable components and must be disaggregated into their respective tradable and non-tradable components. This study assembles the data regarding the outputs of vegetables, imported inputs items (seeds, labour, water, fertilizers, etc.) and market prices for inputs and outputs with the supplementary data such as exchange rate, import, and export tariffs.

\section{Analytical Techniques}

Several techniques of data analysis are applied in this study. Dynamic tool approves to estimate both vegetable productivity and gross margin (GM). The gross margin approach is a common dynamic approach to estimate crop profit. The gross margin formula estimates by subtracting the total variable costs of winter vegetables from gross revenues as exposed in equation (1).

$$
\text { (1) } G M_{w}=P_{u} Q_{u}-\sum P_{i} Q_{i}=G R_{w}-\sum T V C_{w}
$$


Whereas:

$G M_{w}=$ Gross margin for winter vegetables.

$P_{u}=$ Price of output produce and $Q_{u} Q_{u}=$ the total quantity of output produce per hectare.

$P_{i}=$ price of input used (i) and $Q_{i} Q_{i}=$ quantity of inputs used (i).

$G R_{w}=$ Gross revenues for winter vegetables calculated by multiplying the out quantity of yield produced by individual winter vegetable by unit price.

$T V C_{w}=$ Total variable costs for winter vegetables are calculated by multiplying the quantity of vegetable inputs by unit prices. The vegetable net returns are estimated by subtracting the total cost of vegetables from the vegetable gross revenues, as shown in equation (2):

$$
\text { (2) } V N R_{w}=G R_{w}-T C_{W}
$$

Whereas: $V N R_{w}=$ winter vegetables net reruns, $T C_{W}=$ Total cost of winter vegetables. Moreover, the study aims to estimate the CBR of vegetables. Thus, CBR is computed as:

$$
\text { (3) } C B R=\frac{G R_{w}}{T C_{W}}
$$

To achieve the objective of the study for estimating the vegetable protection coefficients and relative efficiency, the table of PAM approach constructs and analyses by GAMS software program syntax. Priyanka et al. (2015) confirmed that PAM is a widely modified policy research analysis, which is a computational framework, developed by Monke and Pearson (1989) and amplified by Masters and Winter-Nelson (1995), for input measuring by using production efficiency, advantage comparative, and the government interventions degree. In addition, the PAM tool assists investigators with conveying the distortions and inefficiencies of a policy, thereby, to suggest the required policy changes for profitability of an industry or a sector or a country (Paulraj et al., 2015). Table 1 shows a PAM model constructed in this study following the basic technique established by Monke and Pearson (1989).

\begin{tabular}{|c|c|c|c|c|}
\hline \multirow{2}{*}{$\begin{array}{c}\text { Prices } \\
\text { (Accounts) }\end{array}$} & \multirow[b]{2}{*}{ Revenue } & \multicolumn{2}{|c|}{ Value of Inputs } & \multirow{2}{*}{$\begin{array}{l}\text { Profit ( surplus } \\
\quad \text { in SR) }\end{array}$} \\
\hline & & $\begin{array}{c}\text { Input cost } \\
\text { (tradable input) }\end{array}$ & $\begin{array}{c}\text { Domestic costs (non- } \\
\text { tradable inputs) }\end{array}$ & \\
\hline Private & $\mathrm{A}$ & $\mathrm{B}$ & $\mathrm{C}$ & $\mathrm{N}$ \\
\hline Social & $\mathrm{D}$ & $\mathrm{E}$ & $\mathrm{F}$ & $\mathrm{O}$ \\
\hline $\begin{array}{c}\text { Divergences } \\
\text { (policy transfer) }\end{array}$ & G & $\mathrm{H}$ & I & $P$ \\
\hline
\end{tabular}

Table 1. Origination of PAM table 


\begin{tabular}{|c|c|c|c|c|}
\hline \multirow[b]{2}{*}{$\begin{array}{c}\text { Prices } \\
\text { (Accounts) }\end{array}$} & \multirow[b]{2}{*}{ Revenue } & \multicolumn{2}{|c|}{ Value of Inputs } & \multirow[b]{2}{*}{$\begin{array}{l}\text { Profit ( surplus } \\
\text { in SR) }\end{array}$} \\
\hline & & $\begin{array}{c}\text { Input cost } \\
\text { (tradable input) }\end{array}$ & $\begin{array}{l}\text { Domestic costs (non- } \\
\text { tradable inputs) }\end{array}$ & \\
\hline
\end{tabular}

*Note: Private profit: $\mathrm{N}=\mathrm{A}-(\mathrm{B}+\mathrm{C})$; Social profit: $\mathrm{O}=\mathrm{D}-(\mathrm{E}+\mathrm{F})$; output transfer: $\mathrm{G}=\mathrm{A}-\mathrm{D}$; Input transfer: $\mathrm{H}=\mathrm{B}-\mathrm{E}$; Factor transfer: $\mathrm{I}=\mathrm{C}-\mathrm{F}$; Net policy transfer: $\mathrm{P}=\mathrm{N}-\mathrm{O}$. Nominal protection coefficient $(\mathrm{NPC})$ on tradable outputs $(\mathrm{NPCO})=\mathrm{A} / \mathrm{E}$, on tradable inputs $(\mathrm{NPCI})=\mathrm{B} / \mathrm{F}$. Effective protection coefficient $(E P C)=(A-B) /(E-F)$. Domestic resource cost ratio $(D R C)=F /(D-E)$. Private profit coefficient $(\mathrm{PPC})=(\mathrm{A}-\mathrm{B}-\mathrm{C}) /(\mathrm{E}-\mathrm{F}-\mathrm{G})$.

Source: Monke and Pearson (1989).

Kanaka and Chinnadurai (2013) stated that the private price is actually the market price, and concerning the social price, assuming social prices would be difficult. Meanwhile, the most difficult accountabilities for PAM construction are estimating social prices for inputs and outputs (Yao 1997b). To compute social prices in this study, the world prices - import price in terms of cost of insurance and freight (CIF) prices for importable and the export prices in terms of free on board (FOB) prices for exportable) are used as the reference prices in the study. These two prices are converted to local price, Saudi Riyal (SR) at the shadow exchanges rate using the foreign exchange rate in $\$(1 \$=3.75 \mathrm{RS})$. Monke and Pearson (1989) stated that world (social) prices denote the government's choice to permit consumers and producers to import, export, or produce commodities domestically, moreover, Sabaouhi et al. (2011) argued that social prices are constraints that limit the agricultural policy, which can affect the quantities that are imported or exported.

Table 1 addresses the important indicators for policy analysis such as: nominal protection coefficient (NPC) used to estimate the vegetable coefficient and domestic resource cost (DRC) and private profit coefficient (PPC) indicators, which are used to estimate the relative efficiency of winter vegetables in this study. Masters and Winter-Nelson (1995) define DRC as the shadow value of non-tradable factor inputs used in an activity per unit of tradable value added. The NPC calculates for both output (NPCO) and input (NPCI) items. Furthermore, the study used the effective protection coefficient (EPC) to measure the total effects of policy intervention in both input and output markets.

\section{Results and Discussion}

The results in Table 2 reflect that the total cultivated areas are highly significant with the vegetable productions $(\mathrm{r}=0.98$, at level $\mathrm{p}<0.01)$, as well as tomatoes estimate the highest share of cultivated area $(56.5 \%)$, hence, the highest share of production $(57.8 \%)$ as compared to the winter vegetables. Whereas, cucumber records the lowest share of cultivated areas and production ( $0.8 \%$ for both). This result supports that the increasing in the total cultivated areas is linked to additional production of vegetables. Nevertheless, eggplant constitutes the highest productivity per hectare (22.6/ton/ha), while ladyfinger comprises the lowest productivity per ha: (15.3 ton/ha) during the study period. Likewise, the study's result exposes a slightly dissimilar area of productivity with winter vegetables. 
Table 2.Comparison analysis of winter vegetables productivity in Al-Hasa Region, 2015/2016.

\begin{tabular}{|c|c|c|c|c|c|c|}
\hline $\begin{array}{c}\text { Winter } \\
\text { vegetables }\end{array}$ & $\begin{array}{c}\text { Cultivated } \\
\text { areas }\end{array}$ & $\begin{array}{c}\text { \% share of } \\
\text { cultivated } \\
\text { areas }\end{array}$ & $\begin{array}{c}\text { Production } \\
\text { /ton }\end{array}$ & $\begin{array}{c}\text { \% share of } \\
\text { production }\end{array}$ & $\begin{array}{c}\text { Productivity } \\
\text { ton / hectare* }\end{array}$ & $\begin{array}{c}\text { Price of } \\
\text { ton in SR }\end{array}$ \\
\hline Tomatoes & 497 & 56.5 & 9350 & 57.8 & 18.8 & 1200 \\
\hline Eggplant & 98 & 11.1 & 2211 & 13.7 & 22.6 & 1000 \\
\hline Zucchini & 131 & 15 & 2139 & 13.2 & 16.3 & 1300 \\
\hline Cucumber & 7 & 0.8 & 137 & 0.8 & 19.6 & 1400 \\
\hline Ladyfinger & 129 & 14.6 & 1973 & 12.2 & 15.3 & 1500 \\
\hline Potatoes & 17 & 2 & 366 & 2.3 & 21.5 & 1400 \\
\hline Total & 879 & 100 & 16176 & 100 & $\mathrm{r}=0.98^{* *},(\mathrm{p}<0.01)$ \\
\hline
\end{tabular}

Source: MoAEW (2017) and authors calculations.

It is obvious that from Table 3, the eggplant estimates a higher gross margin (SR 12296) while the zucchini and the ladyfingers comprised the lowest gross margins, SR 8981 and SR 8565, respectively. According to the CBRs values, the cucumber estimated a higher CBR (2.52), while the eggplant comprised the lowest CBR (1.70).

Table 3. Gross margins balance and CBR of winter vegetables in Al-Hasa Region in SR.

\begin{tabular}{|c|c|c|c|c|c|c|}
\hline $\begin{array}{c}\text { Winter } \\
\text { vegetables }\end{array}$ & $\begin{array}{c}\text { Variables cost } \\
\text { (SR/ ton) }\end{array}$ & $\begin{array}{c}\text { Returns } \\
(\mathbf{S R} / \text { ton) }\end{array}$ & $\begin{array}{c}\text { Gross } \\
\text { margins } \\
\text { (SR) }\end{array}$ & $\begin{array}{c}\text { Total cost } \\
(\mathbf{S R})\end{array}$ & $\begin{array}{c}\text { Net returns } \\
\left(\boldsymbol{V N R}_{\boldsymbol{w}}\right)\end{array}$ & CBR \\
\hline Tomatoes & 10630 & 22575.45 & 10630 & 11752 & 10823.45 & 1.92 \\
\hline Eggplant & 12296 & 22561.22 & 12296 & 13258 & 9303.22 & 1.70 \\
\hline Zucchini & 8981 & 21226.72 & 8981 & 9020 & 12206.72 & 2.35 \\
\hline Cucumber & 10862 & 27400 & 10862 & 10862 & 16538 & 2.52 \\
\hline Ladyfinger & 8565 & 22941.86 & 8565 & 9582 & 13359.86 & 2.39 \\
\hline Potatoes & 12918 & 30141.18 & 12918 & 13452 & 16689.18 & 2.24 \\
\hline
\end{tabular}

Source: MoAEW (2017) and authors calculation.

\section{Production Coefficients of Winter Vegetables}

Fang and Beghin (2000) clarified that the three coefficients used to compare the extent of policy transfers or policy incentives between the agricultural commodities are named as NPCI, NPCO, and EPC. Additionally, these coefficients measure the degree of policy transfer from product market output and tradable input policies (Ul-Mulk and Khan 2013). The outcome values of production coefficients of winter vegetables in this study are illustrated in the Table 4; the values of NPC are diverging among the winter vegetables. The NPCO values are less than one for most of the winter vegetables (83\%), which indicates that the private price of outputs of the tomatoes, eggplant, zucchini, cucumber, and ladyfinger is less than their parity, and hence, the vegetable producers are negatively protected for their production. Whereas, the potatoes estimate NPC $>1$ (for both input and output), indicating that potato producers were receiving more than the world reference price due to subsidy supplied by the government to potato producers. Likewise, this shows that the private price of potato output is more than its parity price; 
hence, the producers of potatoes are positively protected for their production. RebollarRebollar et al. (2011) argued that production of potatoes in the southwest of the State of Mexico was profitable and competitive. Subsequently, the study results revealed that the NPCO of tomatoes is close to one, suggesting that tomato producers are nearly protected through the existing policy.

Table 4. Production coefficients of winter vegetables in Al-Hasa region (2016/2017).

\begin{tabular}{|c|c|c|c|}
\hline \multirow{2}{*}{ Winter vegetables } & \multicolumn{3}{|c|}{ Protection coefficients } \\
\cline { 2 - 4 } & NPCO & NPCI & EPC \\
\hline Tomatoes & 0.90 & 0.17 & 0.172 \\
\hline Eggplant & 0.33 & 1.39 & 1.38 \\
\hline Zucchini & 0.65 & 0.52 & 0.51 \\
\hline Cucumber & 0.70 & 1.16 & 1.17 \\
\hline Ladyfinger & 0.31 & 0.31 & 0.30 \\
\hline Potatoes & 2.80 & 1.01 & 1.01 \\
\hline
\end{tabular}

Source: GAMS Model results.

During the study period, the tomatoes, the zucchini, and the ladyfingers show NPC < 1 (for both inputs and outputs), which indicates that the producers of these vegetables are subsidized and had been largely competitive on exportable basis. Furthermore, the eggplant and the cucumber imply NPCI $>1$, thus suggesting that the government policies are direct to reduce the input costs and reduce the average market prices of producers of theses vegetables to the level below the world prices, which indicates that the government provides efforts to support eggplant and cucumber vegetables. The declining value of EPC indicates an increasing rate of competitiveness of crops and may plausibly due to adoption of advanced production technology (Kanaka and Chinnadurai 2013). From Table 4, the $\mathrm{EPC}_{\mathrm{s}}$ values are greater than 1 for the eggplant (1.38), cucumber (1.17) and potatoes (1.01), which suggests that government policies provide positive incentives to these vegetable producers in the regions, specifically, the eggplant vegetable $(\mathrm{EPC}=1.38)$.

\section{Relative Efficiency of Winter Vegetables}

It is clear that from the Table 5, the PPC values for eggplant (1.40), cucumber (1.17), ladyfinger (1.30) and potatoes (1.01) are much greater than the respective competing other vegetables, which indicates that there are comparative advantages in producing other vegetables, rather than eggplant, cucumber, ladyfinger, and potatoes. Likewise, this indicates that the cost of resources of these vegetables, such as land, labour, and capital, when valued at their private or social shadow prices, exceeds the value added when measured at its opportunity cost. Furthermore, this result indicates that eggplant, cucumber, ladyfingers, and potatoes were produced inefficiently in the region during the study $\left(\mathrm{PPC}_{\mathrm{s}}>1\right)$. Elzaki et al. (2011), argued that the cereal crops in Sudan are produced inefficiently, as their DRC and PPC values are greater than one. 
Table 5. Relative efficiency and ranking of winter vegetables in Al-Hasa region, 2016/2017.

\begin{tabular}{|l|c|c|c|c|}
\hline \multirow{2}{*}{ Vegetables } & \multicolumn{2}{|c|}{ Indicators } & \multicolumn{2}{c|}{$\begin{array}{c}\text { Ranking of vegetables } \\
\text { DRC or PPC < 1 }\end{array}$} \\
\cline { 2 - 5 } & DRC & PPC & DRC & PPC \\
\hline Tomatoes & $\mathbf{0 . 7 9}$ & $\mathbf{0 . 1 7}$ & 5 & $\mathbf{1}$ \\
\hline Eggplant & $\mathbf{0 . 3 1}$ & $\mathbf{1 . 4 0}$ & $\mathbf{3}$ & $\mathbf{6}$ \\
\hline Zucchini & $\mathbf{0 . 6 9}$ & $\mathbf{0 . 5 1}$ & 4 & $\mathbf{2}$ \\
\hline Cucumber & $\mathbf{0 . 2 6}$ & $\mathbf{1 . 1 7}$ & $\mathbf{2}$ & 5 \\
\hline Ladyfinger & $\mathbf{2 . 9 0}$ & $\mathbf{1 . 3 0}$ & $\mathbf{6}$ & $\mathbf{3}$ \\
\hline Potatoes & $\mathbf{0 . 1 4}$ & $\mathbf{1 . 0 1}$ & 1 & \\
\hline
\end{tabular}

Source: GAMS Model results

The different resulted values of the DRC in the Table 5 confirms that the DRC values rely on the decisions made around the agricultural policy intervention and adjustment instruments toward the studied winter vegetables. From the study results, the use of domestic factors of the ladyfingers is socially not profitable (DRC $>1)$, so, this indicates that the costs of the ladyfingers are more than foreign costs or savings. So, the ladyfinger should not be produced domestically and should be imported instead. However, the other winter vegetables show social profitability $(\mathrm{DRC}<1)$. This indicates that the winter vegetables (tomatoes, eggplant, zucchini, cucumber, and potatoes) should be produced domestically and should be exported, rather that imported. The study accomplished by FAO (2004) estimated the comparative advantages of Syrian agro-food commodity and confirmed that in terms of return to domestic factors invested at the social price, olives, tomatoes and oranges have the lowest DRC. Al-Hiary (2015) found that the domestic resource cost (DRC) for olive crops was greater than one, and that there is no efficiency in the use of the local resources, therefore, there is no comparative advantage for production of olive crops in Jorden.

According to the PPC, the priority values for cultivating winter vegetables are motivated by ranking with declining order. Therefore, the vegetable producers are directed to produce tomatoes, zucchini, potatoes, cucumber, ladyfingers, and eggplant accordingly, which is supported by the PAM results in Table 5.

\section{Concluding Remarks}

The study concluded that the private price of outputs of the tomatoes, eggplant, zucchini, cucumber, and ladyfinger is less than its parity; hence, the vegetable producers are negatively protected for their production. Moreover, the potato producers were receiving more than the world reference price due to subsidy supplied by the government to the potato producers, and producers of potatoes are positively protected for their production. The tomato producers are nearly protected through the existing government policy. The study also concluded that the eggplant, cucumber, ladyfingers, and potatoes are produced inefficiency in the region during study period, furthermore, according to the 
PPC, the priority of values for cultivating winter vegetables is motivated by ranking with declining order, therefore, the vegetable producers are directed to produce tomatoes, zucchini, potatoes, cucumber, ladyfingers, and eggplant accordingly. The improvement of the suitable agricultural policy towards the improvement of the production operations is highly needed. It is also desirable to strengthen the international trade cooperation that aims to reduce the fees and facilitate vegetable production, and the removal of policy distortions to raise incentives for the producers is highly recommended for increasing the production of the winter vegetables.

\section{Acknowledgment}

The authors greatly extend thanks to Deanship of Scientific Research at King Faisal University, Al-Ahsa, Saudi Arabia for financial support under Nasher track grant number (186038). In addition, the authors thanks the Ministry of Environment, Water and Agriculture, (MoEWA) in KSA for providing secondary data; special appreciation is expressed to the members of technical unit in the ministry.

\section{Conflict of Interest}

The authors declare no conflict of interest.

\section{References}

1. Al-Hiary, M.A.(2015).Assessing competiveness of Jordanianolive productionpolicy analysis matrix (PAM), https://www.researchgate.net/publication/281030415

2. Arsanti, I.W. and Böhme, M.H. (2008). Evaluation of Profitability and Competitiveness of Vegetable Farming Systems In Upland Areas of Indonesia. J. Acta Hortic. 794: 49-54, https://doi.org/10.17660/ActaHortic.2008.794.5

3. Atiya, B. (2007). Competitiveness and comparative advantage of tomato in Syria. The Mediterranean Conference of Agro-Food Social Scientists. Barcelona, Spain, April 23rd - 25 th 2007. http://www.econ.core.hu/doc/felhiv/MEDCON-Full Program pdf

4. lzaki, RM, Elamin E. and H. SA. (2010). Poverty and agricultural development in Sudan. International journal of Sudan Research, 1(1): 65-081. http:/www.wasd. org.uk/download/poverty-and-agricultural-development-in-sudan/

5. Fang, C. and Beghin, J. C. (2000). Food Self-Sufficiency, Comparative Advantage, and Agricultural Trade: A Policy Analysis Matrix for Chinese Agriculture. CARD Working Papers. 270. http://lib.dr.iastate.edu/card_workingpapers/270

6. Food Agricultural Organization. FAO. Assistance for capacity building through enhancing operation of the national Agricultural Policy Centre. FAO Projects GCP/SYR/006/ITA and TCP/SYR/29006 (A). Retrieved from http:/www.fao. org/3/ad923e/ad923e00.htm (2004).

7. The Food and Agriculture Organization of the United Nations (FAO), Statistics and Information Branch. Fisheries and Aquaculture Department. Retrieved from www. fao.org/fishery/statistics/en (August, 2018). 
8. General Authority of Statistic GAoS .(2017). Agricultural census, 2017. Riyadh. KSA. https://www.stats.gov.sa/en/22

9. General Authority of Statistic GAoS. 2018. Agricultural Census, 2018. Riyadh, KSA. https://www.stats.gov.sa/en/22.

10. Hoang, V. V. and Tran, K. T. (2019) Comparative Advantages of Alternative Crops: A Comparison Study in Ben Tre, Mekong Delta, Vietnam. AGRIS on-line Papers in Economics and Informatics. 11(1): 35-47. DOI 10.7160/aol.2019.110104.

11. Javed, M.S.; Hassan, S.; Adil, S.A and Ghafoor, A .2006. Comparative advantage of cotton production \& its policy implication in Pakistan. Pak. J. of Agri. Sci. (43) 3: 193-196.

12. Kanaka, S and Chinnadurai, M .(2013). The policy analysis matrix of rice cultivation in India. European J. of Physi. and Agric. Sci. 1(1): 8-19.

13. Lbornoz, C. A and Geraldo, L. F. (2018). Trajectory Design for Efficient Crop Irrigation with a UAV. DOI: 10.1109/CCAC.2017.8276401

14. Scheiterle, L. and Birner, R. (2018). Assessment of Ghana's Comparative Advantage in Maize Production and the Role of Fertilizers. Sustainability. 10(11), 4181; https://doi.org/10.3390/su10114181.

15. Lateef, M .A ;.Kasar, A. D and A. A. Mudhi . (2018). Investment priorities in the agricultural scientific research in Iraq using policy analysis matrix approach cereals crops (Rice Amber Al Baraka Buhooth2, Corn Synthetiic Genotype Fajer 1, And Wheat Buhooth). The Iraqi Journal of Agricultural Sciences. 48 (3): 797-811.

16. Sabaouhi, M.; Ghanbari, A.; Tavassoli, F. R. A. and Esmaeilian, Y. (2011). Economic evaluation and Applications of the Policy Analysis Matrix of sole and intercropping of leguminous and cereals Case study: Shirvan city-Iran. African Journal of Biotechnology. 10(78): 17948-17953. http:/www.academicjournals.org/ AJB

17. Masters, W. A., \& Winter-Nelson, A. E. (1995). Measuring the comparative advantage of agricultural activities: Domestic resource costs and the social costbenefit ratio. American Journal of Agricultural Economics, 77(2), 243-250. https:// doi.org/10.2307/1243534

18. Ministry of economic planning. MoEP, (2018). Summary and Priorities of the Tenth Development Plan (2015-2019). Riyadh, Saudi Arabia. https://www.mep. gov.sa/en/

19. Ministry of Environment, Water and Agriculture. MoEWA. (2017). Statistical Books. Riyadh, KSA. https://www.stats.gov.sa/en/929-0

20. Ministry of Environment, Water and Agriculture .MoEWA. (2018). Statistical Yearbook of 2017. Agriculture, water and environment, Issue Number: 53, chapter 5, Riyadh, KSA. https://www.stats.gov.sa/en/929-0

21. Monke, E. and Pearson, S. (1989). The Policy Analysis Matrix for Agricultural Development; Cornell University: Ithaca, NY, USA, 1989; ISBN 0-8014-9551-2.

22. Ministry of water and electricity. MoWE.2015. Statistical report. Centre of statistics and information. Ministry of water and electricity, Riyadh, KSA. 
23. Quddus, M. A. and Mustafa, U. (2011). Comparative Advantage of Major Crops Production in Punjab: An Application of Policy Analysis Matrix. Lahore Journal of Economics, Department of Economics, The Lahore School of Economics, vol. 16(1): 63-94.

24. Mulk. U. Sardar and Khan,M.. (2013). Comparative advantage and competitiveness of pea crop in Khyber Pakhtunkhwa. Sarhad J. Agric. 29(2): 299-306.

25. Paulraj, A. P., Chandrasekaran, M. and Easwaran, N. (2015). Policy analysis matrix approach: Applications, strengths and weaknesses. Agric. Research J. 52(3): 23951435.

26. Rahman, S.; Kazal, M.M.H.; Begum, I.A.; Alam, M.J. (2016). Competitiveness, Profitability, Input Demand and Output Supply of Maize Production in Bangladesh. Agriculture. https://doi.org/10.3390/agriculture6020021

27. Rashid, M. D A. and Matin, MA. (2018). The policy analysis matrix of pulse crops production in Bangladesh. Bangladesh J. of Agric. Research. 43(1):18-24.109-123. DOI: 10.3329/bjar.v43i1.36185

28. Rebollar-Rebollar, S.; Morales-Hernández, J. L.; Hernández-Martinez, J.; GuzmánSoria , E. and Rebollar-Rebollar, A. (2011). Profitability of Potato (Solanum tuberosum L.) Crop in the Southwest of the State of Mexico. Tropical and Subtropical Agroecosystems. 14 (3): 919-925. www.revista.ccba.uady.mx/ojs/index.php/TSA/ article/view/1055/608

29. Stoforos C., Kavcic S., Erjavej E., Mergos G. (2000) Agricultural policy analysis model for Slovenian agriculture. in: Giannias D.A. (ed.), Mergos G. (ed.). Selected readings on economies in transition. Chania : CIHEAM, p. 91-102. (Cahiers Options Méditerranéennes; n. 44). http://om.ciheam.org/om/pdf/c44/00800090.pdf

30. Temesgen, Y.; Tilahun D. and Belay, B. (2014). Production Expansion, Competitiveness and Comparative Advantage of Upland Rice Production: Case of Fogera and Libokemekem Plain in Ethiopia. The International Journal of Applied Economics and Finance, 8: 43-50.DOI: 10.3923/ijaef.2014.43.50

31. Yao, S. (1997a). Comparative Advantages and Crop Diversification: A Policy Analysis Matrix for Thai Agriculture. Journal of Agricultural Economics 48 (2): 211-222. https://doi.org/10.1111/j.1477-9552.1997.tb01146.x

32. Yao, S. (1997 b). Rice Production in Thailand seen Through a Policy Analysis Matrix. Food Policy. 22 (6): 547-560. https://doi.org/10.1016/S0306-9192(98)00007-4 